\title{
Psoriasis is a systemic disease: A proposed approach for inflammation scale calculation
}

\author{
Abdulghani Mohamed Alsamarai', Amina Hamed Ahmed Alobaidii
}

\author{
${ }^{1}$ Departments of Medicine and Microbiology, Tikrit University College of Medicine, Tikrit, Iraq, ${ }^{2}$ Clinical Biochemistry, \\ Kirkuk University College of Veterinary Medicine, Kirkuk, Iraq
}

Corresponding author: Amina Hamed Ahmed Alobaidii, MD PhD, E-mail: aminahamed2006@gmail.com

\begin{abstract}
Background: Psoriasis is a skin disease affecting $2.3 \%$ of the Iraqi population and begins as a local disease with subsequent systemic comorbidities. Aim: The aim was to clarify whether psoriasis is a local or systemic disease. Materials and Methods: A total of 211 subjects with psoriasis and 163 sex- and age-matched controls were included in the study. Serum adiponectin, interleukin-6, interleukin-8, interleukin-10 (IL-10), interleukin-23 (IL-23), interleukin-18 (IL-18), paraoxonase, lipoprotein (a), osteopontin, chemerin, tumor necrosis factor- $\alpha$ (TNF- $\alpha$ ), high-sensitivity C- reactive protein (hs-CRP), bilirubin, D-dimer, and creatinine were determined using commercial kits. Results: There was no significant difference in the mean age and BMI between psoriasis and the control groups. However, there was significantly higher mean serum values of IL-6, IL-8, IL-10, IL-23, lipoprotein (a), chemerin, TNF- $\alpha$, hs-CRP, osteopontin, D-dimer, troponin I, creatinine, bilirubin, and platelet counts in psoriatic patients than in the controls. Meanwhile, the serum mean values of adiponectin, paraoxonase, and cortisol were significantly lower in psoriasis subjects than in the controls. The mathematical model was proposed to clarify whether psoriasis is a systemic or local disease. The application of the model to our data of biomarkers indicated the presence of systemic inflammation in psoriasis. Conclusion: The present study finding suggests that psoriasis is a systemic disease rather than a local skin disease. However, there is a need for the application of the model in a large-scale study.
\end{abstract}

Key words: Psoriasis; Interleukin 10; Interleukin 18; Interleukin 23; Paraoxonase; Lipoprotein (a); Osteopontin; chemerin

\section{INTRODUCTION}

Psoriasis is a skin disease affecting $2.3 \%$ of the Iraqi population [1] and 1-3\% globally [2]. The disease is characterized by a chronic natural history characterized by remission, relapse, and acute exacerbation [3]. Although psoriasis has an obscure etiology, previous studies have suggested that genetic, infectious, immunological, and environmental factors play a role in the induction of the disease $[4,5]$. Psoriasis is induced as a local dermatological disease with subsequent immuno-inflammatory and metabolic changes $[6,7]$.

In the literature, numerous studies have reported systemic changes, such as dyslipidemia, cytokines, and inflammatory and immunologic biomarker abnormalities [8-27]. Some researchers suggest that psoriasis is a systemic disease rather than a local skin disease $[6,7,17,28-35]$. An alternative explanation for the biomarker abnormalities is that the disease is a combined local and systemic syndrome or that the local skin changes are a dermatological manifestation of a systemic disease.

Suggestions that psoriasis is a systemic disease depend on findings of increased or decreased serum or plasma levels of immunological, inflammatory, and metabolic biomarkers $[6,7,17,28-35]$. However, there are conflicting variations in these biomarkers among different studies.

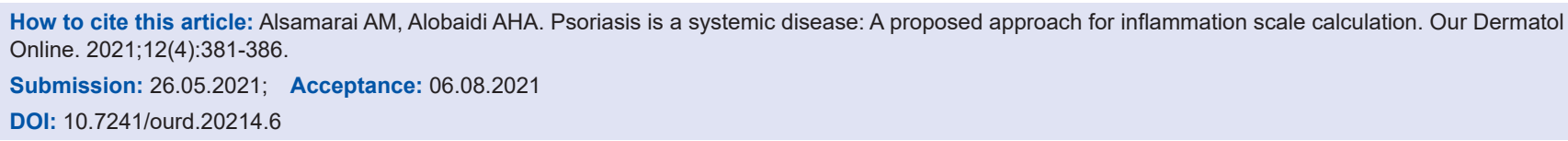


The diagnosis of systemic inflammation with a mathematical model was previously reported for clinical conditions such as obstetric, acute multiple injuries, heart surgery, and sepsis $[36,37]$. Thus, this study proposed a mathematical model for the calculation of a scale that may be employed to diagnose the presence of systemic inflammation in psoriasis and to monitor treatment response of the disease.

\section{MATERIALS AND METHODS}

\section{Study Population}

The present study included 211 subjects with psoriasis attending a dermatology clinic during the period from January 2012 till the end of May 2014.

A total of 163 subjects, sex- and age-matched controls, were included in the study.

The mean age of the patients was $37.85( \pm 14.81)$ years, and that of the control group was 36.76 $( \pm 10.92)$ years with no significant difference between the two groups. Additionally, the mean BMI was $25.83( \pm 6.41)$ in the patients with psoriasis and $25.90( \pm 13.16)$ in the controls, with a nonsignificant difference. The gender frequency rate was not significantly different between the patients and controls (Table 1). The study was approved by the ethical committee of Tikrit University College of Medicine and informed consent was taken from each subject included in the study. Individuals with

Table 1: Biomarkers in the subjects with psoriasis in comparison to the controls

\begin{tabular}{|c|c|c|c|c|}
\hline \multirow[t]{2}{*}{ Biomarker } & \multicolumn{2}{|c|}{ Mean (SD) } & \multirow[t]{2}{*}{$t$} & \multirow[t]{2}{*}{$\mathbf{P}$} \\
\hline & Psoriasis & Controls & & \\
\hline Adiponectin ng/ml & $7.23(3.42)$ & $8.28(5.14)$ & & \\
\hline IL- $6 \mathrm{pg} / \mathrm{ml}$ & 41.85 (13.27) & $4.31(1.87)$ & & \\
\hline IL-8 pg/ml & $47.61(19.77)$ & $7.68(2.32)$ & & \\
\hline IL-10 pg/ml & $8.78(4.81)$ & $5.31(3.73)$ & & \\
\hline IL $-18 \mathrm{pg} / \mathrm{ml}$ & $601.7(247.46)$ & $45.8(23.11)$ & & \\
\hline IL-23 pg/ml & $73.48(29.91)$ & $5.98(6.71)$ & & \\
\hline Paraoxonase $\mathrm{mlU} / \mathrm{ml}$ & $38.96(4.15)$ & 91.65 (16.73) & & \\
\hline Lipoprotein (a) mg/dl & $376.60(35.8)$ & 21.85 (13.62) & & \\
\hline Chemerin ng/ml & $214.88(80.5)$ & $34.31(17.62)$ & & \\
\hline TNF- $\alpha \mathrm{pg} / \mathrm{ml}$ & 277.93 (150.3) & $146.60(90.9)$ & & \\
\hline hs-CRP mg/dl & $3.75(0.74)$ & $1.37(0.39)$ & & \\
\hline D-dimer $\mathrm{ng} / \mathrm{ml}$ & $374.82(261.9)$ & $249.61(217.80)$ & & \\
\hline Cortisol nmol/L & $195.60(37.8)$ & 289.00 (53.11) & & \\
\hline Troponin I ng/ml & $0.27(0.31)$ & $0.04(0.09)$ & & \\
\hline Platelets $10^{3} / \mathrm{mm}^{3}$ & $287(99.7)$ & $256(113)$ & & \\
\hline Bilirubin mg/dl & $1.91(0.17)$ & $0.78(0.09)$ & & \\
\hline Creatinine $\mathrm{mg} / \mathrm{dl}$ & $1.23(0.87)$ & $0.71(0.19)$ & & \\
\hline Osteopontin pg/ml & $638.34(225.80)$ & $45.78(18.95)$ & & \\
\hline
\end{tabular}

(c) Our Dermatol Online 4.2021 liver disease, a family history of hyperlipidemia, diabetes, cardiovascular disease, hypertension, smoking, hypothyroidism, renal disease, connective tissue disease, and those using lipid-lowering drugs were excluded from the study.

\section{Determination of Inflammation}

Inflammatory responses were determined with an approach by Zotova et al. [37], with some modifications. Step 1 involved systemic cellular stress estimation performed using some cytokines and other inflammatory mediators as indicators of systemic inflammatory responses (SIR). In step 2, the systemic inflammation scale was determined by SIR systemic microthrombogenesis, organ dysfunction, systemic alterations, and distress reactions $[38,39]$. The calculation sequences are described below.

1. Calculation of the reactivity index scale (0-6) with the indices shown in Table 2 for IL-6, IL-8, IL-10, IL-18, IL-23, TNF- $\alpha$, hs-CRP, chemerin, lipoprotein (a), paraoxonase, and adiponectin.

2. Calculation of the coefficient of reactivity (CR) [0-36] with the data extracted from Table 2. The sum of $7(60 \%)$ largest RISs from the 11 factors used gave the CR scale.

3. Transformation of the CR scale (0-36) into the reactivity level scale (RLS) with $0-5$ points (40) as shown in Table 3.

4. The Sequential Organ Failure Assessment (SOFA) scale was calculated with the serum level of bilirubin, creatinine, osteopontin, the platelet count, and the presence of sepsis and erythroderma. The SOFA scale was within the range of (0-4) (Table 4).

5. The last step was the calculation of the Systemic Inflammation (SI) scale using the phenomenon described in Table 5.

\section{Investigations}

Serum adiponectin, interleukin-6, interleukin-8, interleukin-10, interleukin-18, interleukin-23, paraoxonase enzyme, lipoprotein (a), TNF- $\alpha$, osteopontin, chemerin, and high sensitivity CRP levels were measured by the enzyme-linked immunosorbent assay. The procedure was performed according to manufacturer instructions.

\section{Statistical Analysis}

Variable values were presented as a mean \pm standard deviation $[\mathrm{SD}]$. The Student's $t$-test was used to 
Table 2: Indices for the calculation of the reactivity index scale (0-6)

\begin{tabular}{|c|c|c|c|c|c|c|c|c|}
\hline \multirow[t]{2}{*}{ Biomarker } & \multirow[t]{2}{*}{ UMN } & \multicolumn{7}{|c|}{ Reactivity Index } \\
\hline & & 0 & 1 & 2 & 3 & 4 & 5 & 6 \\
\hline IL-6 & $6.18 \mathrm{pg} / \mathrm{ml}$ & $\leq 3$ & $\leq 6$ & $\leq 12$ & $\leq 25$ & $\leq 50$ & $\leq 100$ & $>100$ \\
\hline IL-8 & $10 \mathrm{pg} / \mathrm{ml}$ & $\leq 5$ & $\leq 10$ & $\leq 20$ & $\leq 40$ & $\leq 80$ & $\leq 160$ & $>160$ \\
\hline IL-10 & $9.04 \mathrm{pg} / \mathrm{ml}$ & $\leq 1$ & $\leq 2$ & $\leq 5$ & $\leq 10$ & $\leq 20$ & $\leq 100$ & $>100$ \\
\hline IL-18 & $68.91 \mathrm{pg} / \mathrm{ml}$ & $\leq 35$ & $\leq 70$ & $\leq 140$ & $\leq 280$ & $\leq 560$ & $\leq 1120$ & $>1120$ \\
\hline IL-23 & $12.69 \mathrm{pg} / \mathrm{ml}$ & $\leq 5$ & $\leq 10$ & $\leq 25$ & $\leq 50$ & $\leq 100$ & $\leq 200$ & $>200$ \\
\hline TNF $-\alpha$ & $8.01 \mathrm{pg} / \mathrm{ml}$ & $\leq 5$ & $\leq 25$ & $\leq 50$ & $\leq 100$ & $\leq 200$ & $\leq 400$ & $>400$ \\
\hline hs-CRP & $2.76 \mathrm{mg} / \mathrm{dl}$ & $\leq 1$ & $\leq 2$ & $\leq 3$ & $\leq 4$ & $\leq 5$ & $\leq 10$ & $>10$ \\
\hline Chemerin & $51.90 \mathrm{ng} / \mathrm{ml}$ & $\leq 25$ & $\leq 50$ & $\leq 100$ & $\leq 200$ & $\leq 400$ & $\leq 800$ & $>800$ \\
\hline Lipoprotein(a) & $35.45 \mathrm{mg} / \mathrm{dl}$ & $\leq 20$ & $\leq 40$ & $\leq 80$ & $\leq 160$ & $\leq 320$ & $\leq 640$ & $>640$ \\
\hline Paraoxonase & $108.4 \mathrm{mlU} / \mathrm{ml}$ & $>200$ & $\leq 200$ & $\leq 100$ & $\leq 50$ & $\leq 25$ & $\leq 10$ & $\leq 5$ \\
\hline Adiponectin & $13.42 \mathrm{ng} / \mathrm{ml}$ & $>32$ & $\leq 32$ & $\leq 16$ & $\leq 8$ & $\leq 4$ & $\leq 2$ & $\leq 1$ \\
\hline
\end{tabular}

Table 3: Transformation of CR into RL

\begin{tabular}{|c|c|c|}
\hline RL Scale & CR Scale & Inflammation Level \\
\hline 0 & $0-6$ & Normal physiology. \\
\hline 1 & $7-12$ & $\begin{array}{l}\text { Classical inflammation but no systemic } \\
\text { inflammation. }\end{array}$ \\
\hline 2 & $13-18$ & $\begin{array}{l}\text { Typical classical with the possibility of the } \\
\text { depressive phase of systemic inflammation. }\end{array}$ \\
\hline 3 & $19-24$ & Zone of uncertainty. \\
\hline 4 & $25-30$ & $\begin{array}{l}\text { Typical for the hyperergic option of systemic } \\
\text { inflammation with a low possibility of classical } \\
\text { inflammation. }\end{array}$ \\
\hline 5 & $31-36$ & Confirms the presence of systemic inflammation. \\
\hline
\end{tabular}

Table 4: Sequential Organ Failure Assessment (SOFA) scale calculation parameters

\begin{tabular}{lccccc}
\hline Biomarker & \multicolumn{5}{c}{ Scale (0-4) } \\
\cline { 2 - 6 } & $\mathbf{0}$ & $\mathbf{1}$ & $\mathbf{2}$ & $\mathbf{3}$ & $\mathbf{4}$ \\
\hline Bilirubin $\mathrm{mg} / \mathrm{dl}$ & $<1.2$ & $1.2-1.9$ & $2-5.9$ & $6-11.9$ & $\geq 12$ \\
Creatinine $\mathrm{mg} / \mathrm{dl}$ & $<1.2$ & $1.2-1.9$ & $2-3.4$ & $3.5-4.9$ & $\geq 5$ \\
Platelets $10^{3} / \mathrm{mm}^{3}$ & $>150$ & $<150$ & $<100$ & $<50$ & $<20$ \\
Osteopontin pg/ml & $\leq 65$ & $\leq 130$ & $\leq 260$ & $\leq 520$ & $>520$ \\
Sepsis & Negative & Negative & Negative & $\begin{array}{c}\text { Positive } \\
\text { Positive }\end{array}$ & $\begin{array}{c}<12 \text { hrs. } \\
\text { Erythroderma }\end{array}$ \\
& Negative & Negative & Negative & $\begin{array}{c}\text { Positive } \\
\text { Positive }\end{array}$ & $\begin{array}{c}\text { Pos } \\
\end{array}$ \\
& & & & 24 hrs. & $>24$ hrs. \\
\hline
\end{tabular}

Table 5: Parameters for the calculation of the Systemic Inflammation (SI) scale

\begin{tabular}{|c|c|c|}
\hline Phenomenon & Criteria & Points \\
\hline $\begin{array}{l}\text { Systemic Inflammatory } \\
\text { Response } \\
\text { (SIR) }\end{array}$ & Levels RL-scale (0-5) & $2-5$ \\
\hline Microthrombogenesis & D-dimer ( $\geq 500 \mathrm{ng} / \mathrm{ml})$ & 1 \\
\hline Distress Response & Cortisol $(\geq 1380$ or $<100 \mathrm{nmol} / \mathrm{L})$ & 1 \\
\hline Systemic alteration & $\begin{array}{l}\text { Troponin I ( } \geq 0.2 \mathrm{ng} / \mathrm{mL}) \\
\text { Myoglobulin }(\geq 800 \mathrm{ng} / \mathrm{ml})\end{array}$ & 1 \\
\hline $\begin{array}{l}\text { Multiple Organ Dysfunction } \\
\text { (MOD) }\end{array}$ & $\begin{array}{l}\text { SOFA scale and/or other MOD } \\
\text { criteria }\end{array}$ & 1 \\
\hline
\end{tabular}

determine the significant differences between the groups. A P value of less than 0.05 was regarded as significant.

\section{RESULTS}

There was no significant difference in the mean age and BMI between the psoriatic and control groups. However, there was a significantly higher mean serum value of IL-6, IL-8, IL-10, IL-23, lipoprotein (a), chemerin, TNF- $\alpha$, hs-CRP, osteopontin, D-dimer, troponin I, creatinine, bilirubin, and the platelet count in the psoriatic patients than in the controls. Meanwhile, the serum mean values of adiponectin, paraoxonase, and cortisol were significantly lower in the psoriatic subjects than in the controls (Table 1).

\section{DISCUSSION}

The above biomarkers were selected to determine the levels of inflammation based on the reported association between psoriasis and these biomarkers [41]. Previous studies showed an increase in serum levels of IL-6, IL-8, IL-10, IL-23, lipoprotein (a), chemerin, TNF- $\alpha$, hs-CRP, osteopontin, D-dimer, Troponin I, creatinine, bilirubin, creatinine, and the platelet count in patients with psoriasis, and a decrease in the serum levels of adiponectin, paraoxonase, and cortisol [21,32,41-64]. Serum osteopontin was selected as a biomarker for the calculation of the SOFA scale depending on its role as the bridging of adaptive and innate immunity in autoimmune diseases, including psoriasis [65].

Table 6 shows the data of the RI scale calculated as described in Table 2 with the information in Table 5. Then, CR was calculated by the sum of the 7 [60\%] largest values of RIS and, thus, the CR value for the psoriatic patients was 32. According to the criteria presented in Table 3, the CR scale value was 
Table 6: Coefficient Reactivity, the SOFA scale, and the SI scale in patients with psoriasis

\begin{tabular}{|c|c|}
\hline \multicolumn{2}{|c|}{ A. Coefficient Reactivity (CR) calculation $(-36)$} \\
\hline Biomarker & CR points \\
\hline IL-6 & 4 \\
\hline IL-8 & 4 \\
\hline IL-10 & 3 \\
\hline IL-18 & 5 \\
\hline IL-23 & 4 \\
\hline TNF $-\alpha$ & 5 \\
\hline hs-CRP & 5 \\
\hline Chemerin & 5 \\
\hline Lipoprotein(a) & 4 \\
\hline Paraoxonase & 3 \\
\hline Adiponectin & 3 \\
\hline \multicolumn{2}{|c|}{ B. SOFA scale } \\
\hline Biomarker & Point s \\
\hline Bilirubin & 1 \\
\hline Creatinine & 1 \\
\hline Platelets & 0 \\
\hline Osteopontin & 4 \\
\hline Sepsis & 0 \\
\hline Erythroderma & 0 \\
\hline SUM & 6 \\
\hline \multicolumn{2}{|l|}{ B. SI scale } \\
\hline Phenomenon & Points \\
\hline Systemic Inflammatory Response (SIR) & 5 \\
\hline Microthrombogenesis & 0 \\
\hline Distress Response & 0 \\
\hline Systemic Alteration & 1 \\
\hline Multiple Organ Dysfunction (MOD) & 1 \\
\hline SUM & 7 \\
\hline Scale value indicating systemic inflammation & $\geq 5$ \\
\hline
\end{tabular}

transformed into the RL scale and, thus, for our study cohort, the RL scale was 5 (Table 3).

Table 6, shows the SOFA scale calculated according to the criteria presented in Table 4 and, thus, the SOFA scale value for the psoriatic patients was 6 . The systemic inflammation scale $(\mathrm{SI})$ was determined with the criteria presented in Table 5 and, for the psoriatic patients, the SI scale was 7 . The scale cut-off value that indicated systemic inflammation was equal to or above 5 points.

The mathematical model for the diagnosis of systemic inflammation was used previously in other clinical conditions, such as in obstetric, acute multiple injuries, heart surgery, and sepsis $[36,37]$.

\section{CONCLUSION}

The mathematic model presented here is of predictive value in the determination of systemic inflammation and the discrimination between local and systemic inflammation.

\section{Statement of Human and Animal Rights}

All the procedures followed were in accordance with the ethical standards of the responsible committee on human experimentation (institutional and national) and with the 2008 revision of the Declaration of Helsinki of 1975.

\section{Statement of Informed Consent}

Informed consent for participation in this study was obtained from all patients.

\section{REFERENCES}

1. Alsamarai AGM. Prevalence of skin diseases in Iraq. Int J Derm. 2009;48:734-9.

2. Torres T, Bettencourt N. Psoriasis: The visible killer. Rev Port Cardiol. 2014;33:95-9.

3. Alobaidi AHA, Abid I, Alsamarai AGM. Psoriasis: Role of tumor necrosis factor- $\alpha$, interleukin-18, C-reactive protein, 2015, LAMBERT Academic Publishing. Germany.].

4. Sun $\mathrm{L}$, Zhang $\mathrm{X}$. The immunological and genetic aspects in psoriasis. Applied Informatics 2014;1(3). http:/ / www.applied-informatics-j. $\mathrm{com} /$ content $/ 1 / 1 / 3$

5. Alobaidi AHA, Jaber T, Alsamarai AGM. Psoriasis: Paraoxonase and Lipoprotein (a) Role. 2015, LAMBERT Academic Publishing.

6. Reich $\mathrm{K}$. The concept of psoriasis as a systemic inflammation: Implications for disease management. JEADV. 2012;26:3-11.

7. Borska L, Kremlacek J, Andrys C, Krejsek J, Hamakova K, Borsky P, et al. Systemic inflammation, oxidative damage to nucleic acids, and metabolic syndrome in the pathogenesis of psoriasis. Int J Mol Sci. 2017;18:2238.

8. Alobaidi AHA, Abid I, Alsamarai AGM. Psoriasis: Role of Tumor Necrosis Factor- $\alpha$, Interleukin-18, C Reactive Protein, 2015, LAMBERT Academic Publishing. Germany.

9. Alobaidi AHA, Jaber T, Alsamarai AGM. Psoriasis: Paraoxonase and Lipoprotein (a) Role. 2015, LAMBERT Academic Publishing.

10. Alobaidi AHA. Biochemical changes in psoriasis: Lipid profile, oxidant and antioxidant markers. Middle East J Intern Med. 2010;2:27-34.

11. Alobaidi AHA, Mothana Z, Najem WS, Alsamarai AGM. Adiponectin, IL-10, IL-23, and trace element serum levels in patients with psoriasis. Am J Derm Vener. 2012;1:6-23.

12. Coumbe AG, Pritizker MR, Duprez DA. Cardiovascular risk and psoriasis: Beyond the traditional risk factors. Am J Med. 2014;127:12-8.

13. $\mathrm{Al}$ Houssein $\mathrm{RO}, \mathrm{Al}$ Sheikh $\mathrm{A}$. Co-morbidities in psoriatic versus non-psoriatic patients. J Health Spec. 2018;6:82-6.

14. Ghafoor R, Rashid A, Anwar MI. Dyslipidemia and psoriasis: A case control study. J Coll Phys Surg Pakis. 2015;25:324-7.

15. Coimbra S, Santos-Silva A. Biomarkers of psoriasis severity and therapy monitoring. World J Dermatol. 2014;3:15-27.

16. Peluso I, Cavaliere A, Palmery M. Plasma total antioxidant capacity and peroxidation biomarkers in psoriasis. J Biomed Sci. 2016;23:52.

17. Singh S, Young P, Armstrong AW. An update on psoriasis and metabolic syndrome: A meta-analysis of observational studies. PLOS ONE. 2017;12:1-13.

18. Milcic D, Vesic S, Marinkovic J, Jankovic J, Jankovic S, Milinkovic M, et al. Prevalence of metabolic syndrome in patients with psoriasis: A hospital based cross-sectional study. An Bras Dermatol. 2017;92:46-51.

19. Gupta M, Chari S, Borkar M, Chandankhede M. Dyslipidemia and oxidative stress in patients with psoriasis. Biomed Res. 2011;22:222-5. 
20. Rao SV, Kiran VR, Prakash VB. Lipid profile and its relationship to oxidant and antioxidant status in psoriatic arthritis. IJBR. 2014;5:251-3.

21. Saxena R, Suneja S, Saxena R, Sharma D, Lal AM. Systemic inflammation, oxidative stress and apolipoprotein B/A1 ratio in active psoriasis: Bridging an apparent paradox. Int J Res Dermatol. 2015;1:10-3

22. Gui XY, Yu XL, Jin HZ, Zuo YG, Wu C. Prevalence of metabolic syndrome in Chinese psoriasis patients: A hospital based crosssectional study. J Diabetes Investig. 2018;9:39-43.

23. Devi N, Swain S, Padhy RK, Mahapatra S. Study of serum lipid profile and their relationships with oxidant-antioxidant system in patients with psoriasis. Int J Current Med Appli Sci. 2015;7:120-4.

24. Sandhya M, Arun KM, Doddamani BR, Satyanarayana U, Shuruti M. Circulatory markers of oxidative stress and dyslipidemia in male patients of chronic plaque psoriasis. Int J Med Pub Health. 2015;5:208-12.

25. Armstrong AW, Harskamp CT, Armstrong EJ. The association between psoriasis and hypertension: A systematic review and metaanalysis of observational studies. J Hypertens. 2013;31:433-42.

26. Yeung H, Takeshita J, Mehta NN, Kimmel SE, Ogdie A, Margolis DJ, et al. Psoriasis severity and the prevalence of major medical comorbidity: a population based study. Jama Dermatol. 2013;149:1173-9.

27. Alobaidi AHA, Alsamarai AGM. Adenosine deaminase, malondialdehyde, total antioxidant capacity and eosinophil cationic protein in patients with erythroderma. J Invest Biochem. 2013;2:6-13.

28. O' Daly JA. Psoriasis, a systemic disease beyond the skin, as evidenced by psoriatic arthritis and many comorbities - Clinical remission with a leishmania amastigotesvaccine, a serendipity finding. 2012, pp 1-56, InTech publishers. Croatia

29. Cantrell W, Gorelick J, Kucera KJ, Freeman S. Systemic inflammation in psoriasis: A guide for dermatology care providers. Pract Derm. 2018;7:38-45.

30. Takeshita J, Grewal S, Langan SM, Mehta NN, Ogdie A, Van AS, et al. Psoriasis and comorbid diseases: Epidemiology. J Am Acad Dermatol. 2017;76:377-90.

31. Sanz LP. Psoriasis, a systemic disease? Actas Dermosifiliogr. 2007;98:396-402.

32. Dowlatshahi EA, van der Voort EAM, Arends LR, Nijsten T. Markers of systemic inflammation in psoriasis: a systemic review and meta analysis. Br J Der. 2013;169:266-82.

33. Dogan S, Atkan N. Psoriasis: A disease of systemic inflammation with comorbidities. In: Hermenio Lima, Editor, IntechOpen, 2013.P.107-117.

34. Jiang S, Hinchliffe TE, Wu T. Biomarkers of an autoimmune skin disease - Psoriasis. Genomic Proteomic Bioinformatics. 2015;13:224-33.

35. Ridker P. Psoriasis, inflammation, and vascular risk: A problem more than skin deep? Eur Heart J. 2010;31:902-4.

36. Esquivel LAB, Urbina JM, Zeron HM. Approach to an obstetric prognosis scale: The modified SOFA scale. Ghana Med J. 2016;50:129-35.

37. Zotova NV, Chereshnev VA, Gusev EYu. Systemic inflammation: Methodological approaches to identification of the common pathological process. PLOS ONE. 2016;11:e0155138.

38. Gusev EYu, Chereshnev VA. [Systemic inflammation: Theoretical and methodological approaches to description of general pathological process model. Part I. General characteristics of the process]. Pathology Physiology Experimental Therapy. 2012;4:3-14.

39. Gusev EYu, Chereshnev VA. [Systemic inflammation: Theoretical and methodological approaches to description of general pathological process model part IV. The dynamics of the process]. Pathology Physiology Experimental Therapy. 2014;4:4-16.

40. Gusev EYu, Yurchenko LN, Chereshnev VA, Zotova NV, Kopalova YuA, inventors: Institute of immunology and physiology UB RAS, aaignee. [The method of diagnosis and prognosis of systemic inflammation with phases and stage verification]. Russian Federation patent RF 2335771, IPC7G01N33/53.2008 Oct 10. Russian.

41. Kaur S, Kingo K, Zilmer M. Psoriasis and cardiovascular risk- do promising new biomarkers have clinical impact? Mediators Inflamm. 2017;2017:7279818.

42. Murari K. Serum C-reactive protein in psoriasis vulgaris: A casecontrol study in a tertiary care hospital from Southern India. Int J Biochem Res Rev. 2017;17:1-5.

43. Jain K, Krishna A, Rathore BS. Assessing disease severity by hsCRP as a biochemical marker for psoriasis. Int J Res Derm. 2017;3:501-5.

44. Dervisoglu E, Akturk AS, Yildiz K, Kiran R, Yilmaz A. The spectrum of renal abnormalities in patients with psoriasis. Int Urol Nephrol. 2012;44:509-14.

45. Melagaco SSC, Dantas AMM, Siqueira VR, Daher EF, Junior GBS, et al. Evaluation of renal function in patients with psoriasis using immunobiologicals. An Bras Dermatol. 2013;88:667-9.

46. Brunoni AR, Santos IS, Sabbag C, Lotufo PA, Bensenor IM. Psoriasis severity and hypothalamic-pitutary-adrenal axis function: results from the CALIPSO study. Braz J Med Biol Res. 2014;47:1102-6.

47. Hu Y, Yin $\mathrm{L}, \mathrm{Xu}$ J, Yin Z. Renal function of psoriatic patients: Erythrodermic psoriasis has more significant hyperuricemia. Biomed Res. 2017;28:2515-8.

48. Arican O, Aral M, Sasmaz S, Ciragil P. Serum levels of TNF- $\alpha$, IFN- $\gamma$, IL-6, IL-8, IL-12, IL-17, and IL-18 in patients with active psoriasis and correlation with disease severity. Mediat Inflamm. 2005;5:273-9.

49. Smirnova SV, Barilo AA, Smol'nikova MV. Hepatobiliary system diseases as predictors of psoriasis progression. Ann Russ Acad Med Sci. 2016;71:102-8.

50. Mahrous EAM. The relationship between platelet volume and risk of atherosclerosis in patients with psoriasis. Egypt J Der Verner. 2018;38:29-36.

51. Yin L, Xu JL, Hu YY, Johnston A, Yin ZQ. Systemic abnormalities of psoriatic patients: A retrospective study. Clin Cosm Invest Derm. 2016;9:443-9.

52. Yin L, Hu YY, Guo J, Tu J, Yin ZQ. Liver dysfunction in psoriatic patients: Low serum total protein and albumin increase hospital stays. Biomed Res. 2017;28:5997-6001.

53. Saggini A, Chementi S, Chiricozzi A. IL-6 as a druggable target in psoriasis: Focus on pustular variants. J Immunol Res. 2014;2014:964069.

54. Iqbal MN. Levels of interleukins 6 and 8 in psoriatic serum. Ibn Al-Haitham J Pure Appli Sci. 2010;23:1-10.

55. Bai F, Zheng W, Dong Y, Wang J, Garstka MA, Li R, et al. Serum levels of adipokines and cytokines in psoriasis patients: A systematic review and meta analysis. Oncotarget. 2018;9:1266-78.

56. Prathibha K, Nusrath A, Rajeshwari A. Evaluation of serum paroxaonase level and dyslipidemia in psoriasis. Int J Res Med Sci. 2016;4:4001-4.

57. Guzel S, Erfan G, Kulac M, Guzel EC, Kucukyalcin V, Kaya S, Kiziler AR. Chemerin and calprotectin levels correlate with disease activity and inflammation markers in psoriasis vulgaris. Dermatologica Sinica. 2015;33:1-4.

58. Korkmaz S. Mean platlet volume and platelet distribution width levels in patients with mild psoriasis vulgaris with metabolic syndrome. Advan Dermatol Allergol. 2018;35:367-71.

59. Criado PR, Maruta CW, Antinori LCL, Reis VMS. Evaluation of D-dimer serum levels among patients with chronic urticaria, psoriasis and urticarial vasculitis. An Bras Dermatol. 2013;88:355-60.

60. Osterman M, Ayis S, Tuddenham E, Lo J, Lei K, Smith J, et al. Cardiac troponin release is associated with biomarkers of inflammation and ventricular dilation during critical illness. Shock. 2017;47:702-8.

61. Unal M. Platelet mass index is increased in psoriasis. A possible link 


\section{www.odermatol.com}

between psoriasis and atherosclerosis. Arch Med Sci Atheroscler Dis. 2016;1:e145-e9.

62. Vargu M, Vargu P, Heta N, Kondi E, Lezha M. Systemic inflammation in psoriasis vulgaris (study of hs-CRP and alfa-TNF in Albanian psoriatic patients). Int J Sci Res. 2013;4:665-70.

63. Latha KP, Kumar AAS. Serum lipid and lipoprotein (a) levels in psoriasis. Int J Sci Res. 2014;3:283-4.

64. Kyriakou A, Patsatsi A, Vyzantiadis TA, Sotiriadis D. Serum levels of TNF- $\alpha$, IL-12/23P40 and IL-17 in plaque psoriasis and their correlation with disease severity. J Immunol Res. 2014;2014:467541.
65. Clemente N, Raineri D, Cappellano G, Boggio E, Favero F, Soluri MF, et al. Osteopontin bridge innate and adaptive immunity in autoimmune diseases. J Immunol Res. 2016;2016:7675437.

Copyright by Abdulghani Mohamed Alsamarai, et al. This is an open access article distributed under the terms of the Creative Commons Attribution License, which permits unrestricted use, distribution, and reproduction in any medium, provided the original author and source are credited.

Source of Support: Nil, Conflict of Interest: None declared. 